\title{
Culture site dependence on pearl size realization in Pinctada margaritifera in relation to recipient oyster growth and mantle graft biomineralization gene expression using the same donor phenotype
}

\author{
Le Pabic Lore ${ }^{1}$, Parrad Sophie ${ }^{1}$, Sham Koua Manaarii ${ }^{1}$, Seiji Nakasai ${ }^{2}$, Saulnier Denis ${ }^{1}$, \\ Devaux Dominique $^{2,3}$, Ky Chin-Long ${ }^{1, *}$
}

${ }^{1}$ Ifremer, UMR 241, EIO, Labex Corail, Centre du Pacifique, BP 7004, 98719, Taravao, Tahiti, French

Polynesia

2 SCA Regahiga Pearls, BP 48, 98755, Rikitea, Gambier, French Polynesia

${ }^{3}$ Groupement d'Intérêt Economique Poe O Rikitea, BP 176, 98755, Rikitea, Gambier, French Polynesia

*Corresponding author : Ky Chin-Long, email address : chinky@ifremer.fr

\begin{abstract}
:
Size is the most important and valuable quality of the cultured black-lip pearl, Pinctada margaritifera. As this pearl aquaculture is carried out at numerous grow-out sites, this study analyzes the environmental influence on pearl size parameters (nacre weight and thickness) in relation to the recipient oyster biometric parameters (shell thickness, height, width, and oyster weight) at harvest time. Toward this end, an experimental graft was designed by using a homogeneous donor oyster phenotype. The recipient oysters were randomly and equally transferred and reared in five commercial and contrasting grow-out locations. Overall inter-site comparisons revealed that the cultured pearl size $(\mathrm{N}=2168)$ and the biometric parameters of the recipient oysters were highest for sites with warmer temperatures with low seasonal variation in comparison to the southern latitude sites. These results were supported by positive correlations between pearl nacre thickness and recipient oyster shell thickness, height, and width. In parallel, the biomineralization potential of the mantle graft was screened through four genes encoding aragonite (Pif 177, MSI60) and calcite (shematrin 9, aspein). As the gene expression levels were the same among all the donor oysters, this finding demonstrates that: 1) the pearl sac that originated from the mantle graft was not isolated from environmental variations during the culture period and 2) the phenotypic expressions of the two biomineralizing tissues in the recipient oyster were consistent (shell and pearl). In the near future, this knowledge will be helpful at the production sites of genetically selected donor oyster lines for growth produced in hatchery systems.
\end{abstract}




\section{Graphical abstract}

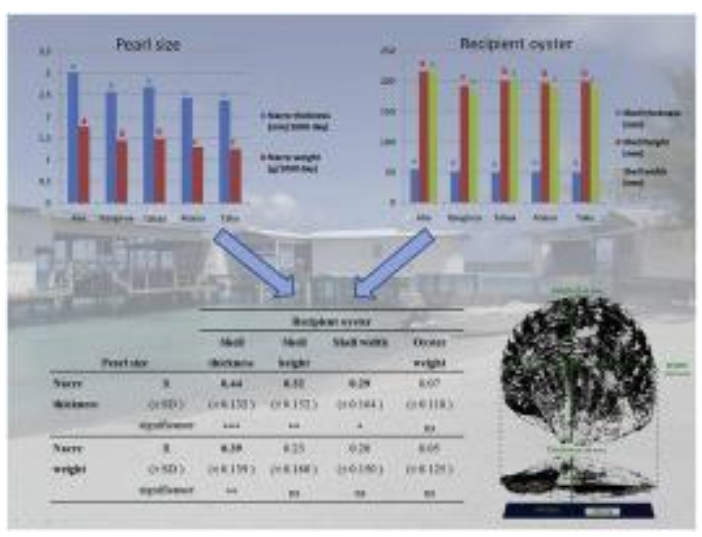

\section{Highlights}

Culture site influence pearl size and recipient oyster growth parameters in $P$. margaritifera. Correlations existed between pearl nacre thickness and recipient oyster shell thickness, height, and width. Biomineralization gene expression levels of the mantle graft were the same among all the donor oysters. - The pearl sac that originated from the mantle graft was not isolated from environmental variations during the culture period.

Keywords: Pinctada margaritifera, cultured pearl size, donor oysters, recipient oysters, gene expression, environmental influences 


\section{Introduction}

The so-called black-lip pearl oyster, Pinctada margaritifera (Linnaeus 1758) var. cumingi (Reeve), is found throughout the Indo-Pacific region. This marine mollusk is particularly abundant in the lagoons of French Polynesia, where it is cultivated for the production of an organic and lucrative gem: the black pearl. In 2013, this industry was developed on 25 islands and atolls, which recorded 517 pearl farms located in three archipelagos: Tuamotu (398 farms), Gambier (79 farms), and Society (40 farms) (Talvard et al., 2015). Today, the black pearl industry remains the second most important economic activity, after tourism, in French Polynesia and is the largest export industry (7.8 billion CFP francs in 2013). Although pearl exports increased by approximately $10 \%$ in 2013, which was the first increase since 2007, revenues remained at a low level (66\% of local product exports) (Talvard et al., 2015). This industry is currently undergoing an economic crisis, with profits showing a continuing decline, due to a combination of factors in which overproduction plays an important role; quantity has been favored to the detriment of quality in the context of a world economic crisis (Le Pennec and Buestel, 2010). Furthermore, it is estimated that only $5 \%$ of harvested pearls can be classed as grade A quality according to the local regulatory control standards (Ellis and Haws, 1999). In this context, an increase in the production of perfect pearls (top gems) would therefore represent a considerable advantage for the industry.

The quality of Tahitian cultured pearls, and hence their value and beauty, is determined based on a wide range of criteria and, with all other quality traits being equal (luster, surface defects, and color), size is one of the most important criteria (Matlins, 1996; Strack, 2006). The cultured pearl size of P. margaritifera typically ranges from $8.0 \mathrm{~mm}$ to 20 $\mathrm{mm}$ (usually issued from a surgreffe operation) (Demmer et al., 2015). This size determines the value of the cultured pearl, with the larger sizes generally commanding the highest prices. According to Tahitian government regulations, all exported pearls must be screened by X-ray technology to ensure that their nacre thickness is at least $0.8 \mathrm{~mm}$. Cultured pearls with thin nacre are rejected. Secretion of the successive nacre layers during the pearl formation originates from the mantle graft. In fact, cultured pearls are produced by grafting a round nucleus made of shell with a piece of mantle from a donor pearl oyster into the gonad of a recipient mollusk. The mantle tissue grows around the nucleus and becomes a pearl sac, which secretes nacreous layers onto the nucleus. This process results in the formation of a cultured pearl in approximately 20 months (Taylor and Strack, 2008). The pearl size achieved depends on several factors, and whether the donor oyster originated from the wild (Tayale et 
al., 2012) or from a farmed family (i.e., produced in a hatchery system) (Ky et al., 2013; Ky et al., 2015a) plays a key role. Jerry et al. (2012) estimated that pearl size is inherited either from the donor oyster or from another pearl oyster species, P. maxima. They revealed genotype by environment $\left(\mathrm{G}^{*} \mathrm{E}\right)$ interaction for pearl size on $P$. maxima reared at two commercial growout locations. In fact, environmental influences have been shown to be important factors to consider (Ky et al., 2015b).

Shell and cultured pearl formations are respectively the result of the biomineralization activities of two distinct tissues: the mantle graft and the pearl sac in the recipient oyster (Ellis and Haws 1999). The shell of $P$. margaritifera consists of two distinct structures: the inner nacreous layer composed of aragonite, and the outer prismatic layer made of calcite. Shell formation is a highly controlled process involving multiple matrix proteins. In P. fucata, the mantle tissue has been seen to be differentiated into two regions, the dorsal "nacreous-layer formation" region and the ventral "prismatic-layer forming" region, so as to produce two clearly distinct shell layers (Takeuchi and Endo, 2006). Cultured pearls are formed by hundreds of thousands of aragonite crystals in a protein matrix that overlap alternately on the nucleus, as observed by electron microscopy (Zhang and Xu, 2013). Nacre is secreted directly by the pearl sac. An increasing number of genes have been identified as coding for mollusk shell matrix components (Huang et al., 2012; Marie et al., 2012; Suzuki and Nagasawa, 2013; Miyamoto et al., 2013), revealing the wide variety of proteins implicated in the biomineralization process.

The present study set out to explore the close relationships between cultured pearl formation and recipient oyster growth in P. margaritifera in relation to the environment (as many pearl farms are geographically distant in French Polynesia), employing multidisciplinary approaches. In particular, when the graft from the donor oyster covers the nucleus to form the pearl sac, we need to ask if this process is isolated from any potential environmental changes: In other words, whether the growth of the cultured pearl is independent from the growth of the recipient oyster. To examine this, a large grafting experiment was designed and the recipient oysters (provided from a single spat collection) were cultivated in five contrasting sites from three archipelagos. The harvested cultured pearls were evaluated for their nacre weight and thickness and four biometric growth parameters of the recipient oyster (sampled from the five grow-out sites) were determined: shell thickness, height, and width, and the weight of the entire oyster (soft tissue parts + shells). This experimental graft was done using the same pool of donor oysters selected on the basis of 
uniform shell color. Their biomineralized mantle graft potential was initially screened through a panel of four representative genes (Pif 177, MSI60, shematrin 9, and aspein) prior to the grafting process (all grafts were performed by a single professional grafter). This knowledge constitutes an initial step in the study of pearl size trait realization, which will be helpful in the near future for the diffusion of genetically selected donor oyster lines produced by hatchery systems for the successful culture of $P$. margaritifera over a wide geographic area.

\section{Materials and Methods}

\subsection{Experimental animals}

Wild Pinctada margaritifera were collected as spat in the lagoon of Mangareva Island (Gambier Archipelago, French Polynesia) to serve as donors and recipients. Passive techniques were employed for catching spat using commercial collectors as described in Ky et al. (2014). After nearly one year of subsurface rearing (3-5 m below the surface), the young pearl oysters (4-5 cm in diameter) were then removed from the collectors on which they had developed. These juveniles were pierced (avoiding living tissues) and tied together onto a Cord Technical Nakasai (CTN) rearing system where they were left until grafting. The CTN was protected using plastic mesh to prevent predation in the lagoon. Mature oysters aged near 20 months, measuring at least $7 \mathrm{~cm}$ in length, were taken from the CTN, detached, and stored ready to be used in the grafting procedure. An expert grafter selected the donor pearl oysters from a set of healthy animals on the basis of their inner shell coloration. The particular donor phenotype selected $(\mathrm{N}=126)$ is illustrated in Figure 1. For this, the grafter used a speculum to gently pry open the oyster's valves. The oysters lacking in coloration were used as recipients.

\subsection{Grafting procedure and experimental design}

The grafting operation was conducted with an expert from the Regahiga Pearl Farm (Mangareva Island-Gambier Archipelago) as described in Ky et al. (2015c). The nuclei used for this purpose were made from the shells of freshwater mussels (1.8 BU size, equivalent to $5.45 \mathrm{~mm}$ diameter, $0.26 \mathrm{~g}$ weight; Imai Seikaku Co. Ltd., Japan) with the thickness and hardness of the nacreous layers showing specific gravity and thermal conductivity that makes them particularly suitable (Gervis and Sims, 1992). The epithelial cells required for grafting were excised from the mantle of the selected donor pearl oysters $(\mathrm{N}=126)$. In that method, small strips of epithelium are prepared before being transplanted into the recipient oysters; the grafts were approximately $4 \mathrm{~mm}^{2}$. 
The grafter first incises the recipient oyster's gonad into which is then placed the nucleus and graft. The entire operation takes 30 seconds. A total of 2520 grafts were performed (20 grafts per donor) over five days. The grafted oysters were placed in separate subdivisions in transparent retention bags (10 grafted oysters per retention bag) with their hinges facing upwards so that the nuclei could not slip out of place due to the pull of gravity. Traceability and correspondence between the grafted oysters and each donor oyster was maintained using plastic numbered labels attached to the retention bags. All the grafted oysters were checked for nucleus retention/rejection and mortality 45 days after the graft experiments, as described in Ky et al. (2014). The oysters that retained their nuclei were drilled (by making a hole through the base of the shell in the dorsal-posterior region, avoiding the living tissues) and fixed onto chaplets (one chaplet was made per original donor oyster after removing the net retention bags).

The recipient oysters grafted from the same donor oyster (chaplets) were then randomly split into five groups; one of the groups was kept at the Regahiga Pearl Farm and reared in Atiaoa Bay (site nomenclature: GMR-Atiaoa), a second group was transferred by boat to Taku Bay (GMR-Taku), another to Mangareva Island Bay, a third group was transferred by plane to the Ahe Atoll, a fourth group was taken to the Rangiroa Atoll, and the fifth and final group was taken to Tahaa Island (Figures 2 and 3).

\subsection{Mantle graft sampling and real-time PCR}

During the grafting operation (and prior to transferring the grafts to the five culture sites), some grafts of the P. margaritifera donor oyster were sampled and preserved in RNAlater (Qiagen) $\left(50 \mathrm{mg} \mathrm{mL}^{-1}\right)$ and stored at $-80^{\circ} \mathrm{C}$ until RNA extraction. For each donor, a total of 24 strips has been prepared. Four of them were randomly selected and pooled in RNAlater. The twenty other strips were used for the grafting process. All the donor were then sampled for gene expression analysis. Among these samples, six individuals per culture site were randomly selected and individually treated for molecular analysis. After removing the RNAlater by pipetting and absorption, the total RNA of each individual graft was extracted using TRIzol Reagent (Invitrogen) and treated with DNAse I using a DNA-free Kit (Ambion) following the manufacturer's instructions. RNA concentrations were measured on an ND-100 spectrophotometer (Nanodrop Technologies) at $260 \mathrm{~nm}$ using the conversion factor $1 \mathrm{OD}=$ $40 \mu \mathrm{g} \mathrm{m} \mathrm{L}{ }^{-1}$ RNA. For each sample, $0.5 \mu \mathrm{g}$ of total RNA was reverse-transcribed using a Transcriptor First Strand cDNA Synthesis Kit (Roche) and amplified by real-time PCR on a 
Stratagene MX3000P system. The expression level of a panel of four genes representative of the biomineralizing activity (Pif 177, MSI60, shematrin 9, and aspein) and two housekeeping genes (gapdhl and Sage 1) were analyzed using quantitative Real-Time PCR (qRT-PCR). The amplification reaction contained 12.5 $\mu \mathrm{L} 2 \mathrm{X}$ SYBR green qPCR Master Mix (Stratagene), $10 \mu \mathrm{L}$ cDNA template, and $2.5 \mu \mathrm{L}$ of the gene primers $(4 \mu \mathrm{M})$ in a final volume of $25 \mu \mathrm{L}$. Each run included a positive cDNA control and a blank control (water) for each primer pair. Relative gene expression was calculated using the two reference genes, gapdh1 and Sage 1, by the $2^{-\Delta \Delta \mathrm{Ct}}$ threshold cycle method (Livak and Schmittgen, 2001), as follows:

$$
\begin{aligned}
& \Delta \mathrm{Ct}_{\text {gene, sample } x}=\mathrm{Ct}_{\text {gene, sample } x}-0.5\left(\mathrm{Ct}_{\text {gapdhl, sample } x}+\mathrm{Ct}_{\text {Sagel, sample } x}\right) \\
& \Delta \Delta \mathrm{Ct}_{\text {gene, sample } x}=\Delta \mathrm{Ct}_{\text {gene, sample } x}-\mathrm{Avg} . \Delta \mathrm{Ct}_{\text {gene, sample } x},
\end{aligned}
$$

Relative expression ${ }_{\text {gene, }}$ sample $x=2^{-\Delta \Delta \mathrm{Ct}}$ gene, sample $x$.

\subsection{Measurement of cultured pearl size and recipient oyster parameters}

After approximately 20 months, the cultured pearls were harvested. The culture period (days post-graft until harvest of the cultured pearls) differed between the sites, as follows: 580 days for Ahe, 591 days for Tahaa, 611 days for both GMR-Taku and GMR-Atiaoa, and 622 days for Rangiroa.

Cultured pearls were cleaned by ultrasonication in soapy water (hand washing) with a LEO 801 laboratory cleaner ( $2 \mathrm{~L}$ capacity, $80 \mathrm{~W}, 46 \mathrm{kHz}$ ); they were then rinsed in distilled water. Pearl size was assessed by nacre thickness and nacre weight. These last two components were measured as described in Blay et al. (2014). Because the culture period differed between the five sites, the nacre weight and thickness values were divided by the number of days of culture in order to obtain comparable daily growth rates. Some keshi (small non-nucleated pearls formed when an oyster rejects and expulses the implanted nucleus during the culture period) were harvested, but not graded.

A total sample of 784 recipient oysters was randomly selected among the five growout locations. They were washed with a high pressure spray to remove epibionts and the following four biometric measurements were taken: shell height, width, and thickness (using Vernier calipers), and total weight (shells + animal) of the recipient oysters (using an electronic balance) (Figure 4). The biometric data were converted into daily measurements, as the culture period differed between the grow-out locations, in order to remove the sampling time effect. 


\subsection{Statistical analysis}

The normality of the data distribution and the homogeneity of variance were tested for pearl size and recipient oyster biometric parameters using the Shapiro-Wilk test and Bartlett's test. When necessary, transformations were used to adjust data to this distribution (logarithm or square roots).

Because outcomes were evaluated for each pearl, a single donor oyster was evaluated several times (repeated measures). Thus, the nacre weight and thickness differences between the grow-out locations were compared using a linear mixed-effects model for repeated measures.

A bootstrap re-sampling approach was used to evaluate the correlations between nacre weight and thickness and the four biometric measures of the recipient oysters. This was done by generating 1000 bootstrap replicates based on Pearson's product moment correlation coefficient. The bootstrap variability estimates were made with $95 \%$ confidence intervals.

The normality and homoscedasticity of the gene relative expression data were checked using the Shapiro-Wilk test and Bartlett's test. One-way ANOVA was performed to determine the possible significant differences between the means of the five groups for each biomineralization gene expression level.

Statistical analysis was performed using R@ version 3.2.1 software (R Foundation for Statistical Computing). The significance threshold was set at $p \leq 0.05$.

\section{Results}

\subsection{Nucleus retention, pearl harvest, and oyster mortality/predation}

At 45 days post-grafting, the nucleus retention, rejection, and oyster mortality or predation rates from the 2520 grafts were $86.1 \%(\mathrm{~N}=2168), 11.6 \%(\mathrm{~N}=294)$, and $2.3 \%(\mathrm{~N}=$ 58), respectively. After 18 months of culture, a total of 1905 cultured pearls and 97 keshi were obtained. The numbers of cultured pearls for each grow-out site is shown in Figure 3.

The cultured pearl harvest rates at each site were: GMR-Atiaoa: 94\%, GMR-Taku: 87\%, Ahe: $90 \%$, Rangiroa: $88 \%$, and Tahaa: $86 \%$. Location was found to have a highly 
significant effect ( $p=0.003$ ) on pearl harvest rate, with the GMR-Atiaoa site presenting a higher rate than the group made up of Rangiroa, Taku and Tahaa, but no significant difference with Ahe.

\subsection{Macro-geographical variations of cultured pearl nacre weight and thickness}

Highly significant differences for both cultured pearl nacre weight and thickness were observed between the grow-out sites $(p<0.001)$ (Table 1). For nacre weight, the highest sample value occurred at the Ahe Atoll location, with a daily nacre weight of $1.76 \times 10^{-3} \mathrm{~g} /$ day on average. By contrast, the lightest cultured pearls were recorded in the Gambier Archipelago, for both the two Atiaoa Bay and Taku Bay locations where the daily nacre weight $\left(1.27 \times 10^{-3} \mathrm{~g} /\right.$ day on average $)$ was $40 \%$ less than it was at the Ahe Atoll site. Intermediate values between the Ahe and Gambier sites were observed for the Rangiroa Atoll and Tahaa Island sites. At those two sites, the weight of the pearls was not significantly different $\left(1.46 \times 10^{-3} \mathrm{~g} /\right.$ day on average $)$ and the size was $17 \%$ smaller than the pearls at the Ahe Atoll location.

The trend for the cultured pearl nacre thickness trait was the same as the trend for the nacre weight (Table 1). On average, the cultured pearls produced at the Ahe location presented a significantly larger daily nacre thickness as compared to the four other locations $(p<0.001)$, with a mean value estimated at $3.02 \times 10^{-3} \mathrm{~mm} /$ day. The mean nacre thickness value observed at the Ahe site was on average $26 \%$ greater than the mean value at the Gambier Archipelago, where both the Atiaoa Bay and Taku Bay locations showed no significant difference $\left(2.40 \times 10^{-3} \mathrm{~mm} /\right.$ day on average $)$. The mean value of the pearls at the Ahe location was $15 \%$ greater than the mean values recorded at Rangiroa Atoll and the Tahaa Island sites $\left(2.62 \times 10^{-3} \mathrm{~mm} /\right.$ day on average $)$; moreover, significant differences for nacre thickness were not found at the time of the pearl harvest.

\subsection{Macro-geographical variations of recipient oyster biometry}

Recipient oyster measures (four variables: thickness, height, width, and weight) showed highly significant differences between the grow-out locations at the harvest $(p<$ 0.001 for all mean comparisons), as shown in Table 2.

The highest recipient oyster thickness value was recorded at the Ahe Atoll location, with a daily shell thickness of $55.39 \times 10^{-3} \mathrm{~mm} /$ day on average. This value was on average $9 \%$ greater than the other four sites and this difference was highly significant $(p<0.001)$. The 
four other sites did not show a significant difference in sample mean values (average daily shell thickness was $50.88 \times 10^{-3} \mathrm{~mm} /$ day).

Among the five grow-out locations, the Ahe site also showed a significantly higher shell height mean with a daily value of $215.7 \times 10^{-3} \mathrm{~mm} /$ day on average (Table 2 ). This value was $13 \%$ higher than the Rangiroa Atoll daily value $\left(191.7 \times 10^{-3} \mathrm{~mm} /\right.$ day in average $)$ and 8.5\% higher than the three other locations (two Mangareva Island bays and Tahaa Island lagoon: $198.9 \times 10^{-3} \mathrm{~mm} /$ day on average).

For the shell width, the highest mean value was also observed at the Ahe Atoll site with an average value of $214.6 \times 10^{-3} \mathrm{~mm} /$ day (Table 2). This value was $17 \%$ higher than the Rangiroa Atoll site $\left(183.7 \times 10^{-3} \mathrm{~mm} /\right.$ day on average $), 13 \%$ higher than the two Gambier Archipelago sites $\left(190.2 \times 10^{-3} \mathrm{~mm} /\right.$ day on average $)$, and $8 \%$ higher than the Tahaa Island site $\left(199.1 \times 10^{-3} \mathrm{~mm} /\right.$ day on average $)$.

For recipient oyster weight (Table 2), the daily measurements were significantly higher at the Tahaa Island site $\left(426.4 \times 10^{-3} \mathrm{~mm} /\right.$ day $)$ in comparison with the four other growout sites, which where statistically comparable with an average daily weight of $368.5 \times 10^{-3}$ $\mathrm{mm} /$ day. This value was $14 \%$ lower than the value observed at the Tahaa Island site. In addition, a small dispersion of oyster weight was recorded at the Ahe Atoll site (the standard deviation of the sample values was 0.037 ) in comparison with the value at the four other grow-out locations ( 0.086 on average).

\subsection{Correlation analysis of the cultured pearl and recipient oyster parameters}

The cultured pearl nacre weight and thickness traits were highly correlated. Indeed, the Pearson's correlation coefficient was $+0.94(\mathrm{CI} 95 \%=[0.933 ; 0.943])$ for all locations. The intra-site correlations were also significant $(p<0.001)$ : 0.89 for Atiaoa Bay, 0.94 for Taku Bay, 0.97 for the Ahe Atoll, 0.96 for the Rangiroa Atoll, and 0.91 for Tahaa Island.

High positive correlation coefficients were also observed for each pair of the recipient oyster parameters and the tests for the association between these variables were all significant (Figure 5). The correlation coefficient between shell height and width was the highest: +0.82 and $p<0.001$. The second most important correlation coefficient was observed between shell height and oyster weight $(+0.74)$, and the third most important correlation coefficient was observed between shell width and oyster weight $(+0.69)$. Moderate correlation coefficients 
were obtained for the relationships between shell thickness and the three other traits (shell height, width, and oyster weight: $+0.56,+0.55$, and +0.55 , respectively).

Results of the correlation analysis between the cultured pearl nacre and the recipient oyster parameters are shown in Table 3. Significant coefficients ranged from 0.29 to 0.44 . Cultured pearl thickness and weight were both correlated to recipient oyster thickness with + 0.44 and +0.39 , respectively. Weak but significant positive relationships were obtained between nacre thickness and shell height $(+0.32)$ and shell width $(+0.29)$. In addition, there was no significant relationship between the recipient oyster weight and cultured pearl size parameters for nacre weight for both shell height and oyster thickness.

\subsection{Relative biomineralization gene expression levels in the donor oyster mantle grafts}

The relative expression levels of the four biomineralization genes that were analyzed (Pif 177, MSI60, shematrin 9 and aspein) in the donor oyster mantle graft sample provided from each of the five grow-out locations is shown in Figure 6. The inter-site comparison revealed no significant difference in the relative expression levels of the four biomineralization genes considered.

\section{Discussion}

\subsection{Variations in the phenotype parameters in relation to the environmental site of the culture}

For the nacre thickness and weight parameters in this experiment, the cultured pearls at the Ahe Atoll location showed the most significant growth, followed by the Rangiroa Atoll and the Tahaa Island sites, then by the two Mangareva Island bay locations. For this inter-site comparison, made at the macro-geographic scale, the environmental parameters (i.e., water temperature, nutrient levels), including seasonal variability, were deliberately not reported. Indeed, one goal of this study was to evaluate the impact that culture locations in French Polynesia had on pearl size realization over a wide geographic area. From a practical point of view, in the near future these findings will be helpful for selecting an appropriate site for the diffusion of phenotypically selected oyster lines produced in hatchery systems.

Both the environmental knowledge about the contrasting grow-out locations and the impact that food availability and temperature have on growth contribute to explaining the overall geographical growth variability observed in the present study. Indeed, these two main 
environmental parameters have been shown to influence growth and the biomineralization process in bivalves (Laing, 2000; Pouvreau and Prasil, 2001; Schöne et al., 2005). For $P$. margaritifera cultured pearl growth, Joubert et al. (2014) tested combinations of temperature and microalgal concentrations over a period of two months and revealed that the expression levels of Pif 177 and shematrin 9 were higher for a high microalgal concentration and that this was correlated to the nacre deposition rate. For oyster shell growth, Linard et al. (2011) used microscopy to show that the thickness of the newly formed aragonite tables were thinnest for oysters that had been treated under a low trophic regime ( 800 cells $/ \mathrm{mL}$ vs. 15000 cells $/ \mathrm{mL}$ ). At the macro-geographical scale, the potential food resources for pearl oysters in Polynesian lagoons has already been evaluated in relation to differences in particulate organic matter (POM) concentrations (Charpy et al., 1997). In this study, the authors observed a strong dependency between the level of POM and the atoll/island latitude. They concluded that the northern atolls of the Tuamotu Archipelago are enriched by nutrient-rich waters derived from Peruvian and equatorial upwellings. They also reached a conclusion about the specific site morphology: the more the lagoons are isolated from the ocean, the higher their phytoplankton biomass was. In general, the POM concentration in lagoons was two to five times higher than it was in oceanic waters. This variation was dependent on the size of the lagoon and the number of natural passages (passes), which facilitate entrances and exits between the massive Pacific Ocean and the protected lagoons. The Ahe Atoll is situated in the northern part of the Tuamotu Archipelago and is relatively isolated in comparison to the Rangiroa Atoll. Thus, this helps explain why the cultured pearl size parameters and the shell thickness, height, and width of the recipient oysters were the highest in the Ahe Atoll and the lowest in the Rangiroa Atoll (Fournier et al., 2012). This must also be related to temperature differences between the latitudes of these two sites. The Ahe Atoll is situated in the northern part of the Tuamotu Archipelago and the annual average lagoon water temperature is high with low seasonal variations $\left(27.3^{\circ} \mathrm{C}\right.$ to $29.2^{\circ} \mathrm{C}$ in 2012) compared to those observed in the Gambier Archipelago $\left(21.3^{\circ} \mathrm{C}\right.$ to $28.8^{\circ} \mathrm{C}$ in 2012$)$. These contrasting latitude temperatures partially explain the lowest levels of cultured pearl parameters that were observed for the two Gambier sites. In the present study, the intermediate cultured pearl parameter values observed for the Rangiroa and Tahaa locations are supported by another experimental graft conducted in 2011 (submitted to the present Special issue).

\subsection{Environment influence of the gene expression level of the two recipient oyster biomineralization tissues}


The panel of genes selected for the present study encodes proteins that are implicated in the pearl oyster shell biomineralization process. Four genes representative of this process, as two genes involved in the formation of aragonite (Pif177 and MSI60) and two genes involved in the formation of calcite (shematrin 9 and aspein), were selected. The protein gene Pif177 regulates the growth of the aragonite crystal and the organization of the tablets (Suzuki et al., 2009). This protein has been identified in P. margaritifera (Joubert et al., 2014). The protein gene MSI60 regulates both the growth and the nucleation of the aragonite crystal (Xiang et al., 2013). Two protein genes were implicated in the calcite mineralization process: shematrin 9 and aspein (Suzuki et al., 2004; Tsukamoto et al., 2004). Yano et al. (2006) suggested that the proteins of the shematrin family make the formation of calcite prisms easier. The aspein gene protein plays a key role in calcite precipitation within the prismatic layers (Isowa et al., 2012).

Nacre thickness and weight are directly correlated with the nacre biomineralization process in P. margaritifera. The epithelial cells from the outer surface of the mantle tissue (which lines the inner surface of the shell) are capable of synthesizing different calcium carbonate polymorphs (Wilbur, 1964; Watabe, 1988), which overlap the nucleus, as observed by electron microscopy (Zhang and $\mathrm{Xu}, 2013$ ). The genome of the donor oyster and its influence on the pearl biomineralization process are still present and active in the pearl sac of the recipient oyster at the end of pearl formation (Arnaud-Haond et al., 2007). McGinty et al. (2011) demonstrated that the donor oyster is an important contributor to the mineralization process in a pearl culture. High biomineralization capabilities may have contributed to a greater nacre deposition, as already observed in P. maxima (Kono et al., 2000; Müller, 1997; Strack, 2006). The difference observed in cultured pearl parameters in the present study seems not to be attributed to potentially different biomineralisation capabilities of the donors phenotype selected (6 individuals per site). In fact, no significant gene expression level difference was observed according to the representative panel used (Pif 177, MSI60, shematrin 9, and aspein) from the donor oyster mantle grafts, which were also randomly dispatched to the different grow-out sites.

Several positive correlations were observed between the cultured pearl size and the shell biometric parameters. In fact, cultured pearl nacre thickness showed a significant positive correlation with recipient oyster shell thickness, height, and width, whereas nacre weight was correlated to shell thickness. This was consistent with the findings from studies on $P$. fucata, where phenotypic correlations between pearl weight and shell traits were observed 
(Wada, 1984; Velayudan et al., 1996; He et al., 2008). In P. fucata martensii, positive correlations between the cultured pearl size parameters (diameter, weight, and nacre thickness) and the morphometric parameters of the recipient oyster (weight and shell height) have also been detected (Wada and Komaru, 1966; Wang et al., 2013). This suggests that the recipient oyster affects the activities of the two biomineralizing tissues (the mantle and the pearl sac), especially the pearl sac. In fact, the nucleus had no direct contact with the recipient oyster; it was enveloped within the pearl sac. The recipient oyster can affect pearl development in two key ways. First, the recipient oyster regulates the metabolism of the pearl sac, which is dependent upon nutrient supply throughout the period of culture. In an appropriate environment, the recipient oyster can supply a high level of nutrients suitable for both the pearl sac and the mantle graft, and then promote the nacre secretion rates for the formation of the cultured pearl and the shell, respectively. Secondly, recipient oysters can regulate the expression of the biomineralization genes in the two corresponding tissues. In this way, the expression levels of those genes in the two tissues are controlled by the same recipient oyster.

\section{Conclusion}

The culture site and growth environment of grafted recipient oysters play a key role in cultured pearl size determination and shell growth in $P$. margaritifera. The present study was the first to use the same donor oyster phenotype to examine the macro-geographical impact on pearl size realization at five grow-out sites. The relative homogeneity of the donor oyster selected was suggested at a molecular level through its relative biomineralization potential (screened in the mantle graft tissue by a representative panel of four genes involved in the formation of aragonite (Pif177 and MSI60) and calcite (shematrin 9 and aspein)). Based on the geographic location (latitude), food availability, and temperature of the site, consistent interpretations were found for the cultured pearl and recipient oyster shell parameters, which were the highest at the northern site (Ahe Atoll) in comparison to the intermediate sites (Rangiroa Atoll and Tahaa Island), and the southern sites (Gambier Archipelago).

This study represents an initial step toward the cartography of cultured pearl quality traits among large and contrasting culture sites offered for the aquaculture of $P$. margaritifera. In the future, this quality trait mapping could provide information about the most appropriate culture site environment for the growth of both oyster resources (in hatchery systems) and cultured pearl production. Integration of the expression of other pearl quality traits (color, 
luster, etc.) and their interactions with pearl and shell growth will provide important knowledge for current work on P. margaritifera pearl oyster breeding programs. This study also open the way for physiological investigations, in particular those concerning the nutrition of the recipient oysters in relation to environmental parameters (temperature, food availability, etc), that could be acquired by using on site multi-parametric probe. These complementary studies will help us understanding how climate change will potentially impact Polynesian culture site, and thus prepare the pearl industry to face these global changes.

\section{Acknowledgements}

Authors are grateful to the team at the Regahiga Pearl Farm (Mangareva IslandGambier Archipelago-French Polynesia) for the experimental grafts and the maintenance of the oyster cultures. 


\section{References}

Arnaud-Haond S., Goyard E., Vonaun V., Herbaut C., Prou J., Saulnier D., 2007. Pearl formation: persistence of the graft during the entire process of biomineralization. Marine Biotechnology, Vol. 9, pp. 113-116.

Blay C., Sham-Koua M., Vonau V., Tetumu R., Cabral P., Ky C.L., 2014. Influence of nacre deposition rate on cultured pearl grade and colour in the black lipped pearl oyster Pinctada margaritifera using farmed donor families. Aquaculture International, Vol. 22, Issue 2, pp. 937-953.

Charpy L., Dufour P., Garcia N., 1997. Particulate organic matter in sixteen Tuamotu atoll lagoons (French Polynesia). Marine Ecology Progress Series, Vol. 151, pp. 55-65.

Demmer J., Cabral P., Ky C.L., 2015b. Comparison of harvested rate and nacre deposition parameters between cultured pearls issued from initial graft and second nucleus insertion in P.margaritifera. Aquaculture Research, in press.

Ellis S., Haws M., 1999. Producing Pearls Using the Black-lip Pearl Oyster. Center for Tropical and Subtropical Aquaculture Publication, Vol. 141.

Fournier J., Dupuy C., Bouvy M., Couraudon-Réale M., Charpy L. Pouvreau S., Le Moullac G., Le Pennec M., Cochard J.C., 2012. Pearl oysters Pinctada margaritifera grazing on natural plankton in Ahe atoll lagoon (Tuamotu archipelago, French Polynesia). Marine Pollution Bulletin, Vol. 65, Issues 10-12, pp.490-499.

Gervis M.H., Sims N.A., 1992. The biology and culture of pearl oysters (Bivalvia: Pterridae). ICLARM Stud., Rev. 21, pp. 49.

He M., Guan Y., Yuan T., Zhang H., 2008. Realized heritability and response to selection for shell height in the pearl oyster Pinctada fucata (Gould). Aquaculture Research, Vol. 39, pp. 801-805.

Huang X.D., Zhao M., Liu W.G., Guan Y.Y., Shi Y., Wang Q., Wu S.Z., He M.X., 2013. Gigabase-Scale Transcriptome Analysis on Four Species of Pearl Oysters. Marine Biotechnology, Vol. 15, Issue 3, pp. 253-264. 
Isowa Y., Sarashina I., Setiamarga DH., Endo K., 2012. A comparative study of the shell matrix protein aspein in pterioid bivalves. Journal of Molecular Evolution, Vol. 75, pp. $11-18$.

Jerry D.R., Kvingedal R., Lind C.E, Evans B.S., Taylor J.J.U., Safari A.E., 2012. Donoroyster derived heritability estimates and the effect of genotype $\times$ environment interaction on the production of pearl quality traits in the silver-lip pearl oyster, Pinctada maxima. Aquaculture, Vol. 338-341, pp. 66-71.

Joubert C., Linard C., Le Moullac G., Soyez C., Saulnier D., Teaniniuraitemoana V., Ky C.L., Gueguen Y., 2014. Temperature and Food Influence Shell Growth and Mantle Gene Expression of Shell Matrix Proteins in the Pearl Oyster Pinctada margaritifera. PLoS ONE, Vol. 9, Issue 8.

Kono M., Hayashi N., Samata T., 2000. Molecular mechanism of the nacreous layer formation in Pinctada maxima. Biochemichal and Biophysical Research Communications. Vol. 269, Issue 1, pp. 213-218.

Ky C.L., Blay C., Aiho V., Cabral P., Le Moullac G., Lo C., 2015b. Macro-geographical differences influenced by family-based expression on cultured pearl grade, shape and colour in the black-lip pearl oyster Pinctada margaritifera : a preliminary case study in French Polynesia. Aquaculture Research, in press.

Ky C.L., Blay C., Lo C., 2015a. Half-sib families effect on cultured pearl quality traits in the black-lipped pearl oysters Pinctada margaritifera: testing for indirect benefits of polyandry and polygyny. Aquaculture International, in press.

Ky C.L., Blay C., Sham Koua M., Vanaa V., Lo C., Cabral P., 2013. Family effect on cultured pearl quality in black-lipped pearl oyster Pinctada Margaritifera and insights for genetic improvement. Aquatic Living Resources, Vol. 26, Issue 2, pp. 133-145.

Ky C.L., Molinari N., Moe E., Pommier S., 2014. Impact of season and grafter skill on nucleus retention and pearl oyster mortality rate in Pinctada margaritifera aquaculture. Aquaculture International, Vol. 22, pp. 1689-1701.

Ky C.L., Nakasai S., Molinari N., Devaux D., 2015c. Influence of grafter skill and season on cultured pearl shape, circles and rejects in Pinctada margaritifera aquaculture in Mangareva lagoon. Aquaculture, Vol. 435, pp. 361-370. 
Laing I., 2000. Effect of temperature and ration on growth and condition of king scallop Pecten maximus spat. Aquaculture, Vol. 183, Issues 3-4, pp. 325-334.

Le Pennec, M., Anastas, M., Bichet, H., Buestel, D., Cochard, J.C., Cochennec-Laureau, N., Coeroli, M., Conte, E., Correia, P., Fougerousse-Tsing, A., Langy, S., Le Moullac, G., Lo C., Peltzer, L., Pham, A., 2010. Huître Perlière et Perle de Tahiti. HQ Imaging, Faaa, French Polynesia.

Linard C., Gueguen Y., Moriceau J., Soyez C., Hui B., Raoux A., Cuif J.P., Cochard J.C., Le Pennec M., Le Moullac G., 2011. Calcein staining of calcified structures in pearl oyster Pinctada margaritifera and the effect of food resource level on shell growth. Aquaculture, Vol. 313, pp. 149-155.

Livak K.J., Schmittgen T.D., 2001. Analysis of Relative Gene Expression Data Using RealTime Quantitative PCR and the $2^{2 \mathrm{DDC}}{ }_{\mathrm{T}}$ Method. Elsevier Science, Vol. 25, No. 4, pp. 402-408.

Marie B., Joubert C., Tayale A., Zanella-Cléon I., Belliard C., Piquemal D., CochennecLaureau N., Marin F., Gueguen Y., Montagnani C., 2012. Different secretory repertoires control the biomineralization processes of prism and nacre deposition of the pearl oyster shell. PNAS, Vol. 109, No. 51.

Matlins A.L., 1996. The pearl book: the definitive buying guide. Gemstone Press, $3^{\text {rd }}$ ed.

McGinty E.L., Evans B.S., Taylor J.U.U., Jerry D.R., 2010. Xenografts and pearl production in two pearl oyster species, P. maxima and P. margaritifera : Effect on pearl quality and a key to understanding genetic contribution. Aquaculture, Vol. 302, pp. 175-181.

McGinty E.L., Zenger K.R., Taylor J.U.U., Evans B.S., Jerry D.R., 2011. Diagnostic genetic markers unravel the interplay between host and donor oyster contribution in cultured pearl formation. Aquaculture, Vol. 316, pp. 20-24.

Miyamoto H., Endo H., Hashimoto N., Limura K., Isowa Y., Kinoshita S., Kotaki T., Masaoka T., Miki T., Nakayama S., Nogawa C., Notazawa A., Ohmori F., Sarashina I., Suzuki M., Takagi R., Takahashi J., Takeuchi T., Yokoo N., Satoh N., Toyohara H., Miyashita T., Wada H., Samata T., Endo K., Nagasawa H., Asakawa S. and Watabe S., 2013. The 
Diversity of Shell Matrix Proteins: Genome-Wide Investigation of the Pearl Oyster, Pinctada fucata. Zoogical Science, Vol. 30, No. 10, pp. 801-816.

Müller A., 1997. Cultured Pearls - The First Hundred Years. Golay Buchel USA Ltd., pp. 142.

Pouvreau S., Prasil V., 2001. Growth of the black-lip pearl oyster, Pinctada margaritifera, at nine culture sites of French Polynesia: synthesis of several sampling designs conducted between 1994 and 1999. Aquatic Living Resources. Vol. 14, pp. 155-163.

Schöne B.R., Houk S.D., Freyre Castro A.D., Fiebig J., Oschmann W., Kröncke I., Dreyer W., Gosselck F., 2005. Daily growth rates in shells of Arctica islandica: assessing subseasonal environmental controls on a long-lived bivalves mollusk. Society for Sedimentary Geology. Vol. 20, pp. 78-92.

Strack E., 2006. Pearls. Rülhe-Diebener-Verlag GmbH \& Co., Stuttgart, Germany, pp. 706.

Suzuki M., Murayama E., Inoue H., Ozaki N., Tohse H., Kogure T., Nagasawa H., 2004. Characterisation of prismalin-14, a novel matrix protein from the prismatic layer of the japanese pearl oysetr (Pinctada fucata). Biochem J., Vol. 382, pp. 205-213.

Suzuki M., Nagasawa H., 2013. Mollusk shell structures and their formation mechanism. Can. J. Zool. Vol. 91, pp. 349-366.

Suzuki M., Saruwatari K., Kogure T., Yamamoto Y., Nishimura T., Kato T., Nagasawa H., 2009. An acidic matrix protein, Pif, is a key macromolecule for nacre formation. Science, Vol. 325, pp. 1388-1390.

Takeuchi T., Endo K., 2006. Biphasic and dually coordinated expression of the genes encoding major shell matrix proteins in the pearl oyster Pinctada fucata. Marine biotechnology, Vol. 8, pp. 52-61.

Talvard C., Challier S., 2015. La perle en 2013 : les exportations de produits perliers progressent en 2013. Points Forts Bilans, ISPF, Vol. 1.

Tayale A., Gueguen Y., Treguier C., Le Grand J., Cochennec-Laureau N., Montagnani C., Ky C.L., 2012. Evidence of donor effect on cultured pearl quality from a duplicated 
grafting experiment on Pinctada Margaritifera using wild donors. Aquatic Living Resources. Vol. 25, pp. 269-280.

Taylor J.J.U., Strack E., 2008. Pearl production. The Pearl Oyster, eds. Southgate P.C. and Lucas J.S., Elsevier, chap. 8, pp. 273-302.

Tsukamoto D., Sarashina I., Endo K., 2004. Structure and expression of an unusually acidic matrix protein of pearl oyster shells. Biochemical and Biophysical Research Communications, Vol. 320, No. 4, pp. 1175-1180.

Velayudan T.S., Chellam A., Dharmaraj S., Victor A.C.C., Kasim H.M., 1996. Comparison of growth and shell attributes for four generations of pearl oyster Pinctada fucata (Gould) produced in the hatchery. Indian Journal of Fisheries, Vol. 43, pp. 69-77.

Wada K.T., 1984. Breeding study of the pearl oyster Pinctada fucata. Bull. Natl. Res. Inst. Aquaculture, Vol. 6, pp. $79-157$.

Wada K.T., Komaru A., 1996. Color and weight of pearls produced by grafting the mantle tissue from a selected population for white shell color of the Japanese pearl oyster Pinctada fucata martensii (Dunker). Aquaculture, Vol. 142, pp. 25-32.

Wang N., Kinoshita S., Riho C., Maeyama K., Nagai K., Watabe S., 2009. Quantitative expression analysis of nacreous shell matrix protein genes in the process of pearl biogenesis. Comparative Biochemistry and Physiology, Vol. 154, Part B, pp. 346-350.

Wang S.Y., Xin H.Z., Zhifeng G., Aimin W., 2013. The influence of Saibo Donor and Host on the Nacre Deposits of Pearls Produced from Pinctada Fucata Martensii. Journal of Shellfish Research, Vol. 32, No. 2, pp. 271-274.

Watabe N., 1988. Shell structure. The Mollusca, Trueman E.R. and Clarke M.R. (Eds.), Academic Press, Vol. 11, pp. 69-104.

Wilbur K., 1964. Shell formation and regeneration, Physiology of Mollusca, A. Saleuddin, K. Wilbur (Eds.), Academic P, pp. 243-287.

Xiang L., Su J., Zheng G., Liang J., Zhang G., Wang H., Xie L., Zhang R., 2013. Paterns of expression in the matrix proteins responsible for nucleation and growth of aragonite crystals in flat pearls of Pinctada fucata. PLoS ONE, Vol. 8, pp. 6-9. 
Zhang G., Xu J., 2013. From colloidal nanoparticles to a single crystal: new insights into the formation of nacre's aragonite tablets. Journal of Structural Biology, Vol. 182, pp. 3643.

Zhang L., He M., 2011. Quantitative expression of shell matrix protein genes and their correlations with shell traits in the pearl oyster Pinctada fucata. Aquaculture, Vol. 314, pp. 73-79.

Yano M., Nagai K., Morimoto K., Miyamoto H., 2006. Shematrin: a family of glycine-rich structural proteins in the shell of the pearl oyster Pinctada fucata. Comparative Biochemistry and Physiology, Part B: Biochemistry and Molecular Biology, Vol. 144, Issue 2, pp. 254-262. 
Table 1: Pinctada margaritifera cultured pearl nacre weight $(\mathrm{g})$ and thickness $(\mathrm{mm})$ harvested from the five grow-out locations: Ahe Atoll and Rangiroa Atoll (Tuamotu Archipelago), Tahaa Island (Society Archipelago), and the Atiaoa Bay and Taku Bay locations from Mangareva Island (Gambier Archipelago). Means values correspond to daily measurements multiplied by a factor 1000 . For each location, standard deviation (SD) and the median and inter-quartile range $\left(\mathrm{Q}_{1}-\mathrm{Q}_{3}\right)$ are presented. The data means that were significantly different between the five grow-out sites at $p \leq 0.001$ are indicated with three asterisks $(*)$. The data points that were significantly different at $p<0.05$ are indicated with letters between the locations.

\begin{tabular}{lccccccc}
\cline { 3 - 7 } & & $\begin{array}{c}\text { Ahe } \\
(389)\end{array}$ & $\begin{array}{c}\text { Rangiroa } \\
(404)\end{array}$ & $\begin{array}{c}\text { Tahaa } \\
(422)\end{array}$ & $\begin{array}{c}\text { Atiaoa } \\
(376)\end{array}$ & $\begin{array}{c}\text { Taku } \\
(314)\end{array}$ & Significance \\
\hline Nacre & Mean & $\mathbf{1 . 7 6}^{\mathrm{a}}$ & $1.44^{\mathrm{b}}$ & $1.48^{\mathrm{b}}$ & $1.30^{\mathrm{c}}$ & $1.25^{\mathrm{c}}$ & $* * *$ \\
weight & $( \pm \mathrm{SD})$ & $( \pm 0.45)$ & $( \pm 0.38)$ & $( \pm 0.33)$ & $( \pm 0.34)$ & $( \pm 0.32)$ & \\
& & & & & & \\
& Median & 1.64 & 1.31 & 1.43 & 1.20 & 1.17 & $* * *$ \\
& $\left(\mathrm{Q}_{1}-\mathrm{Q}_{3}\right)$ & $(1.25-2.14)$ & $(1.04-1.68)$ & $(1.08-1.82)$ & $(0.91-1.52)$ & $(0.92-1.51)$ & \\
\hline Nacre & Mean & $\mathbf{3 . 0 2}^{\mathrm{a}}$ & $2.56^{\mathrm{b}}$ & $2.68^{\mathrm{b}}$ & $2.43^{\mathrm{c}}$ & $2.37^{\mathrm{c}}$ & $* * *$ \\
thickness & $( \pm \mathrm{SD})$ & $( \pm 0.76)$ & $( \pm 0.65)$ & $( \pm 0.56)$ & $( \pm 0.57)$ & $( \pm 0.54)$ & \\
& & & & & & & \\
& Median & 2.95 & 2.48 & 2.64 & 2.41 & 2.33 & $* * *$ \\
& $\left(\mathrm{Q}_{1}-\mathrm{Q}_{3}\right)$ & $(2.47-3.50)$ & $(2.09-2.96)$ & $(2.20-3.16)$ & $(1.92-2.81)$ & $(1.92-2.74)$ & \\
\hline
\end{tabular}


Table 2: Pinctada margaritifera recipient oyster shell thickness (mm), height (mm), width (mm), and total oyster weight (g) in the five grow-out locations: Ahe Atoll and Rangiroa Atoll (Tuamotu Archipelago), Tahaa Island (Society Archipelago) and the Atiaoa Bay and Taku Bay locations from Mangareva Island (Gambier Archipelago). The means values correspond to the daily measurements multiplied by a factor 1000. For each location, standard deviation (SD) and the median and interquartile range $\left(\mathrm{Q}_{1}-\mathrm{Q}_{3}\right)$ are presented. The data means that were significantly different between the five grow-out sites at $p \leq 0.001$ are indicated with three asterisks $\left(^{*}\right.$ ). The data points that are significantly different at $p<0.05$ are indicated with letters between the locations.

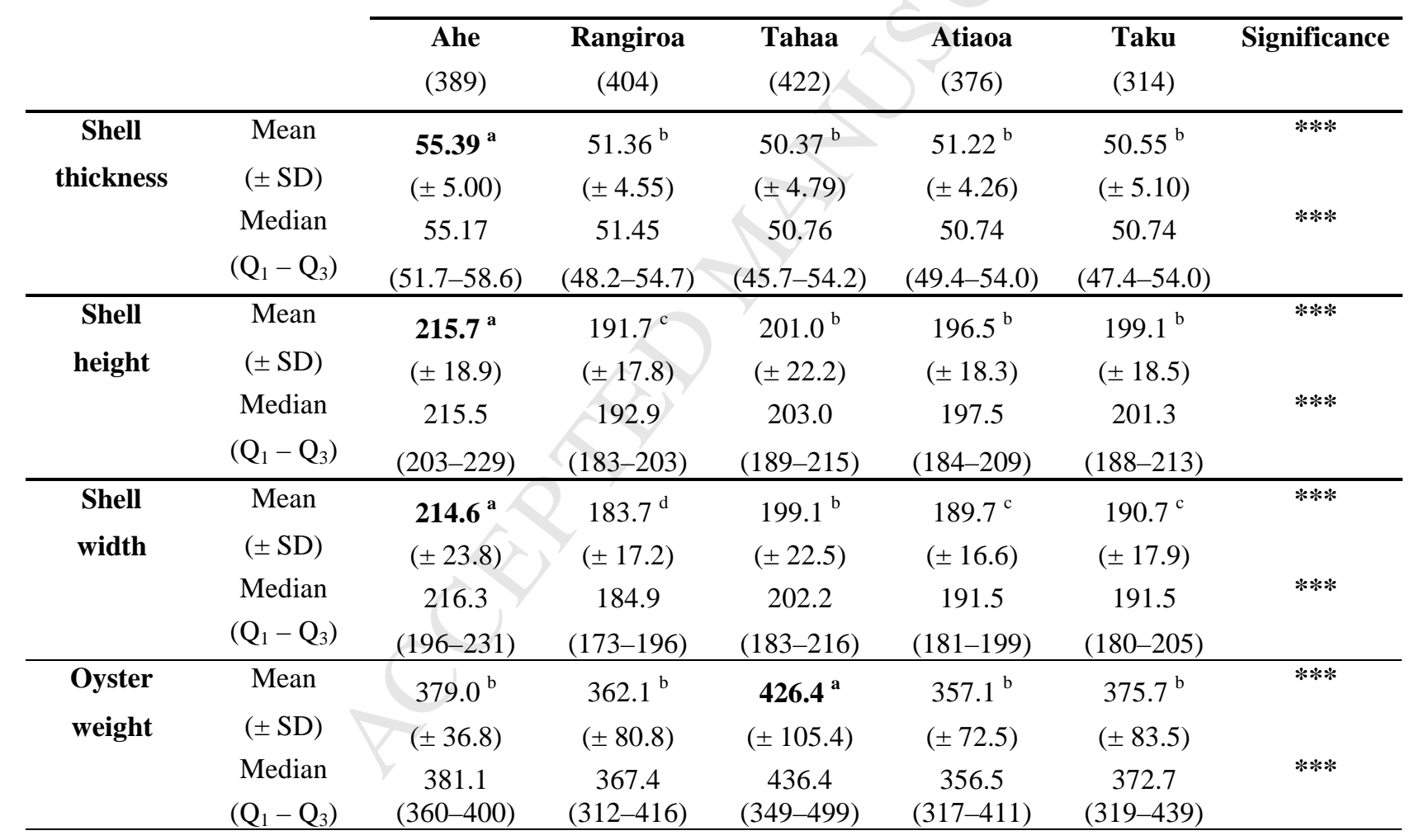


Table 3: Correlation coefficient estimates $(\mathrm{R})$ between the cultured pearl size parameters (nacre thickness and weight) and the recipient oyster shell biometric traits (shell thickness, height, and width, and total oyster weight) in Pinctada margaritifera evaluated from bootstrap replicates. Lower and upper limits of the 95\% confidence interval (CI lower and CI upper) and standard deviation (SD) for the measure of the association are presented. $P$-values correspond to the test for the association between the measures using the Pearson product moment correlation coefficient. Significant associations are indicated with one, two, or three 3 asterisk(s) $(*)$ at $0.01<p \leq 0.05,0.001<p \leq 0.01$, and $p \leq 0.001$, respectively, and NS for not significant.

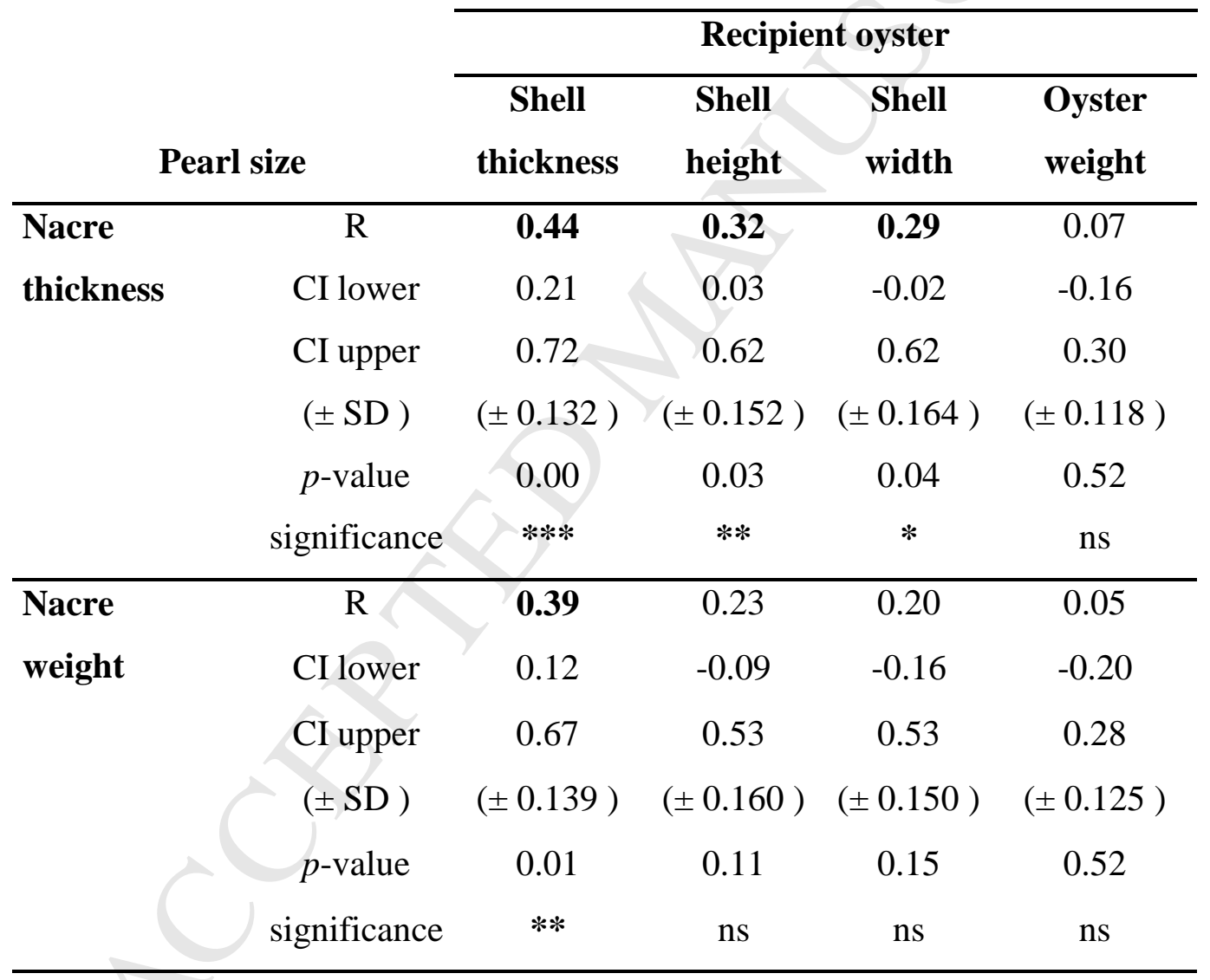


Figure 1: Pinctada margaritifera donor selection based on both outer and inner shell coloration phenotypes for the experimental grafts.

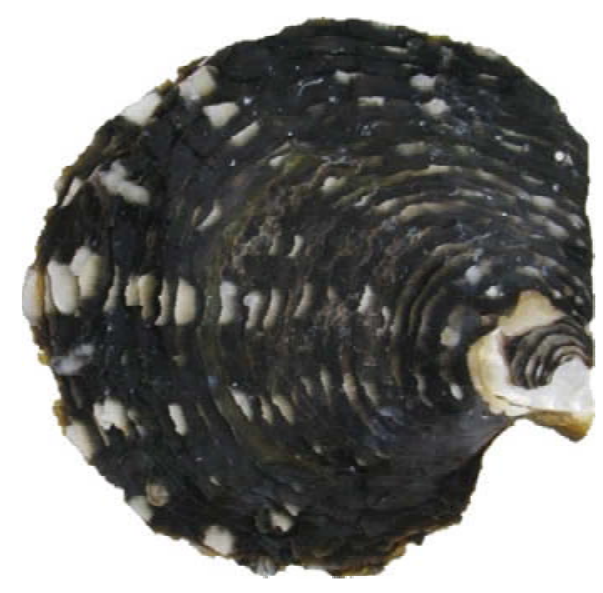

\section{Outer shell phenotype}

Black [B]

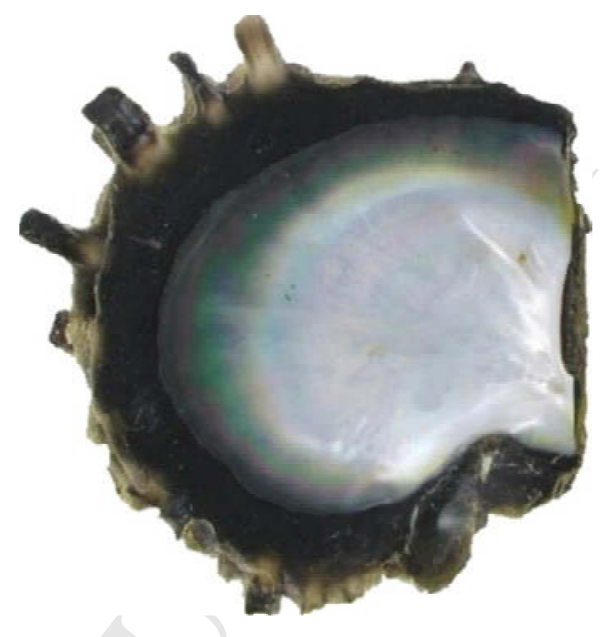

Inner shell phenotype

Green $[\mathrm{G}]$ 


\section{ACCEPTED MANUSCRIPT}

Figure 2: Geographic location of the five grow-out sites where the experimental grafts of Pinctada margaritifera took place. The location in the upper part of the map is French Polynesia in the South Pacific Ocean (halfway between California and Australia). This overseas territory of France is divided into five archipelagos (lower map): the Austral, Gambier, Marquesas, Society, and Tuamotu archipelagos. The five grow-out locations were: the Ahe Atoll and the Rangiroa Atoll (Tuamotu Archipelago), Tahaa Island (Society Archipelago), and the Atiaoa Bay and Taku Bay locations from Mangareva Island (Gambier Archipelago).

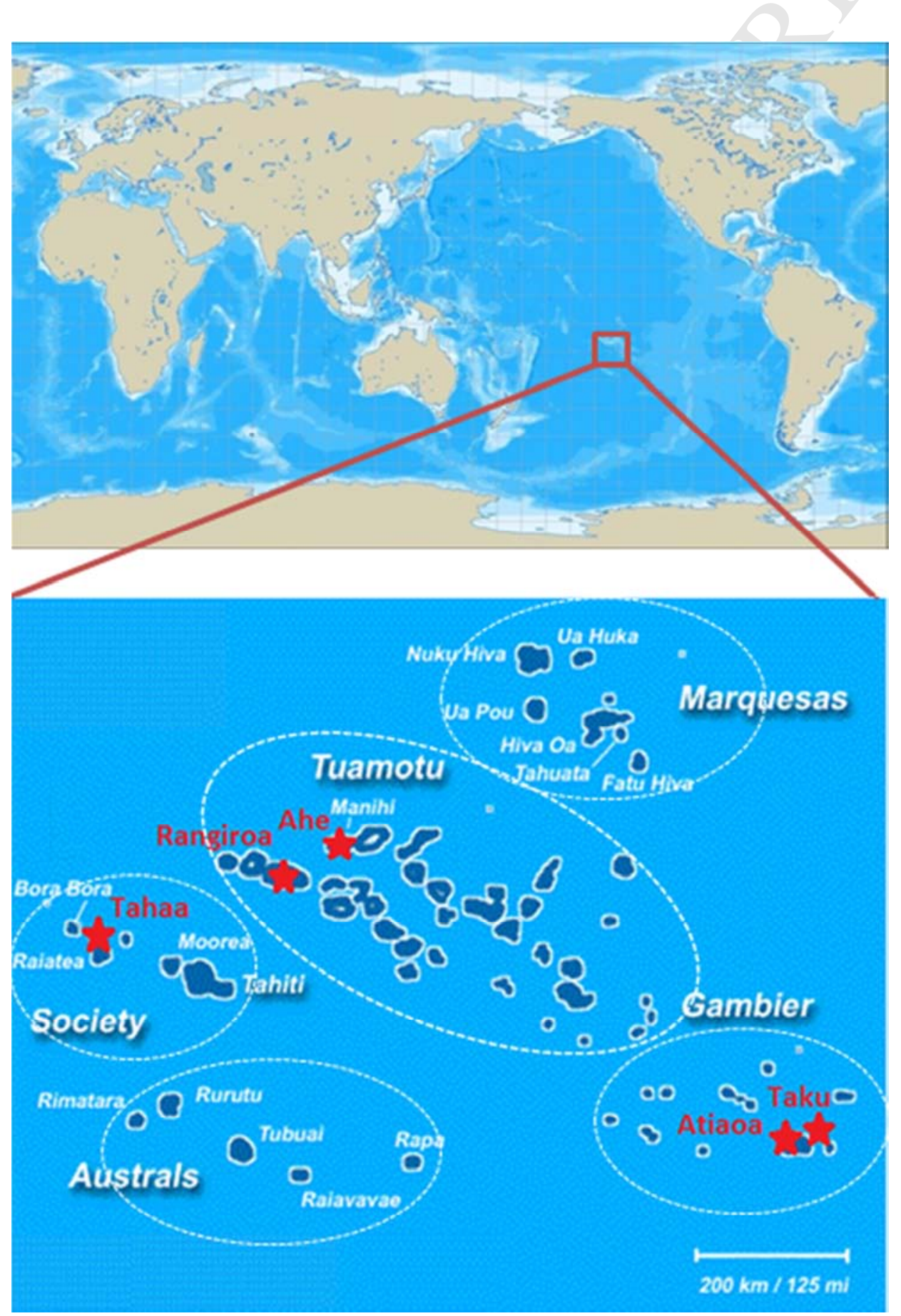


Figure 3: Experimental design of the grafting procedure for the P. margaritifera donors. All 2520 graft operations were performed in Atiaoa Bay (GMR-Atiaoa) at Mangareva Island. After checking, the recipient oysters grafted from each donor oyster were randomly split into five groups; one group was left at GMR-Atiaoa, one group was transferred to Taku Bay (GMR-Taku), another site at Mangareva Island, one was transferred to the Ahe Atoll, one group was transferred to the Rangiroa Atoll, and the final group was transferred to Tahaa Island. The number below each of the locations corresponds to the number of cultured pearls harvested at that site. Black stars show the pearl farm location in the lagoons at the islands or the atolls.

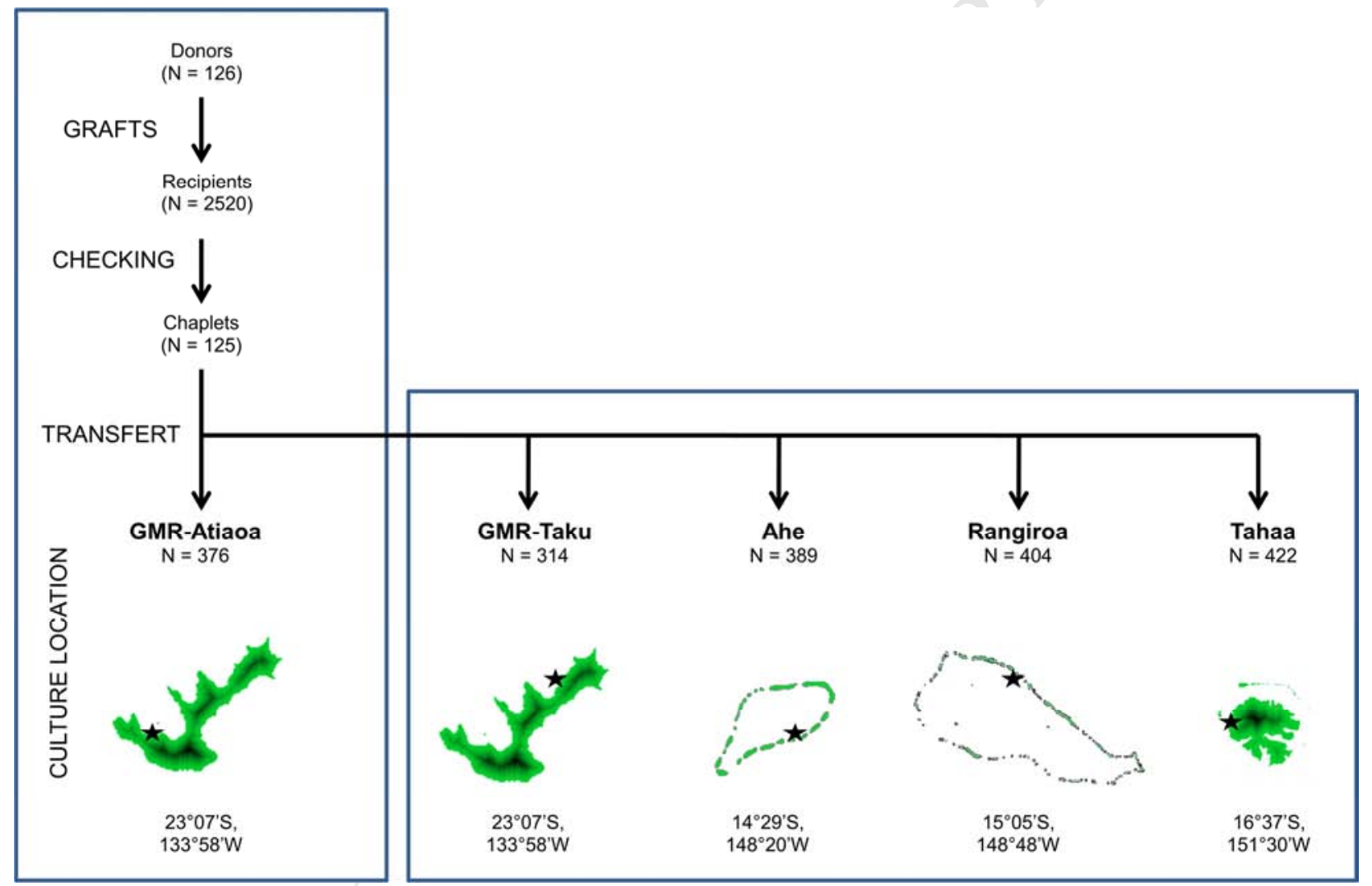


Figure 4: Pinctada margaritifera recipient oyster shell biometry parameters as measured in the experimental grafts: shell height, width, and thickness, and the total oyster weight (soft tissue parts + shells).

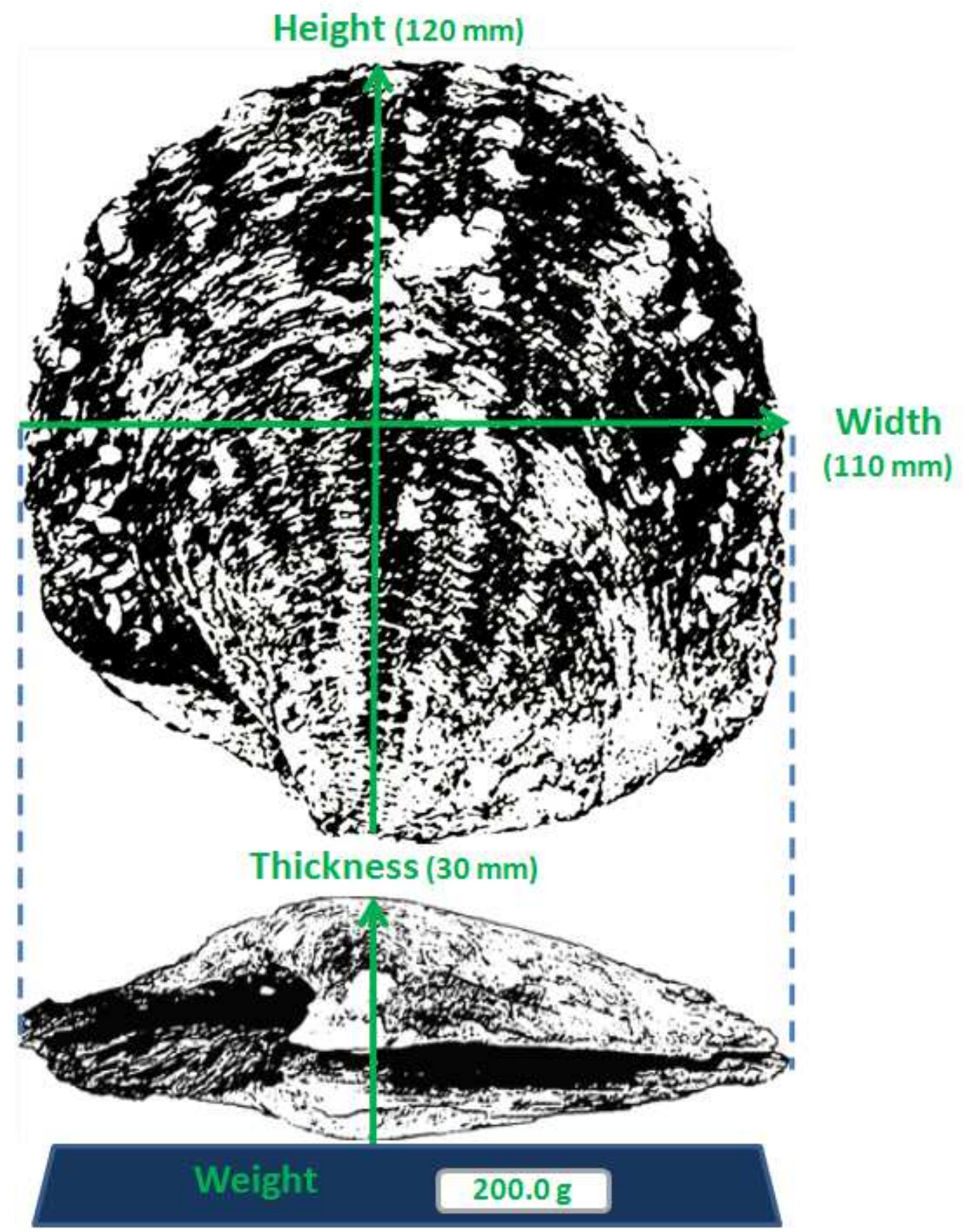


Figure 5: Pairs plot between the Pinctada margaritifera shell biometry parameters: shell height, width, and thickness, and the oyster weight. Correlation values are presented in the upper panel; histograms in the diagonal and scatter plot matrix are displayed in the lower panel. Daily measurements were used to remove the time effect.

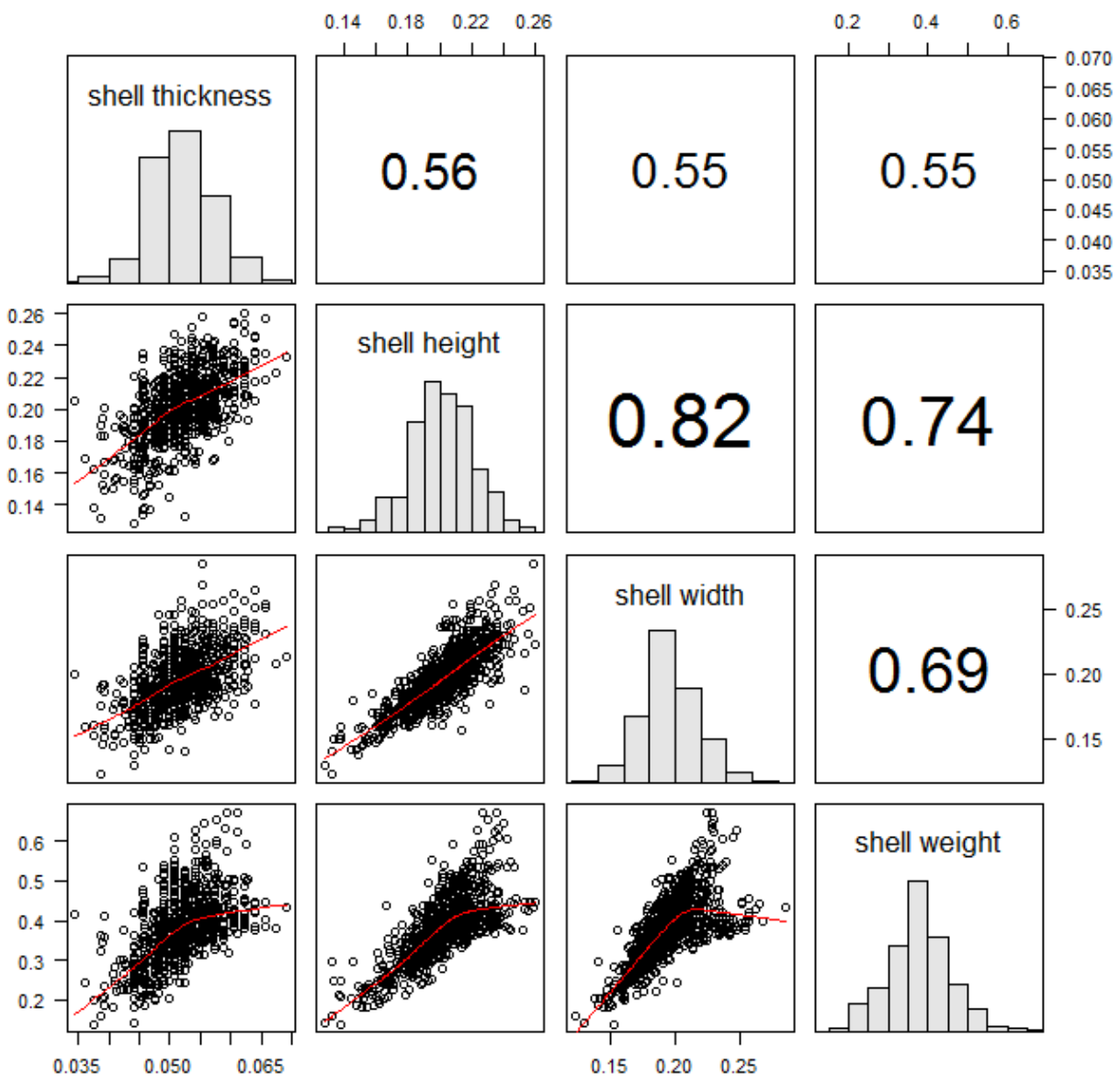


Figure 6: Relative expression of four genes $\left(2^{-\Delta \Delta \mathrm{Ct}}\right)$ coded for proteins of the nacreous and prismatic layers (Pif 177, MSI60, shematrin 9, and aspein) in the mantle graft from selected donors of Pinctada margaritifera from the five locations prior to transfer to the Ahe Atoll and the Rangiroa Atoll (Tuamotu Archipelago), Tahaa Island (Society Archipelago), and the Atiaoa By and Taku Bay locations at Mangareva Island (Gambier Archipelago). Bar means correspond to the relative gene expression mean from six donor oysters per location (minus the expression of housekeeping genes and centered). For each group comparison, the p-value (pv) of the one-way ANOVA test is represented on the bar plot, as well as the confidence intervals.
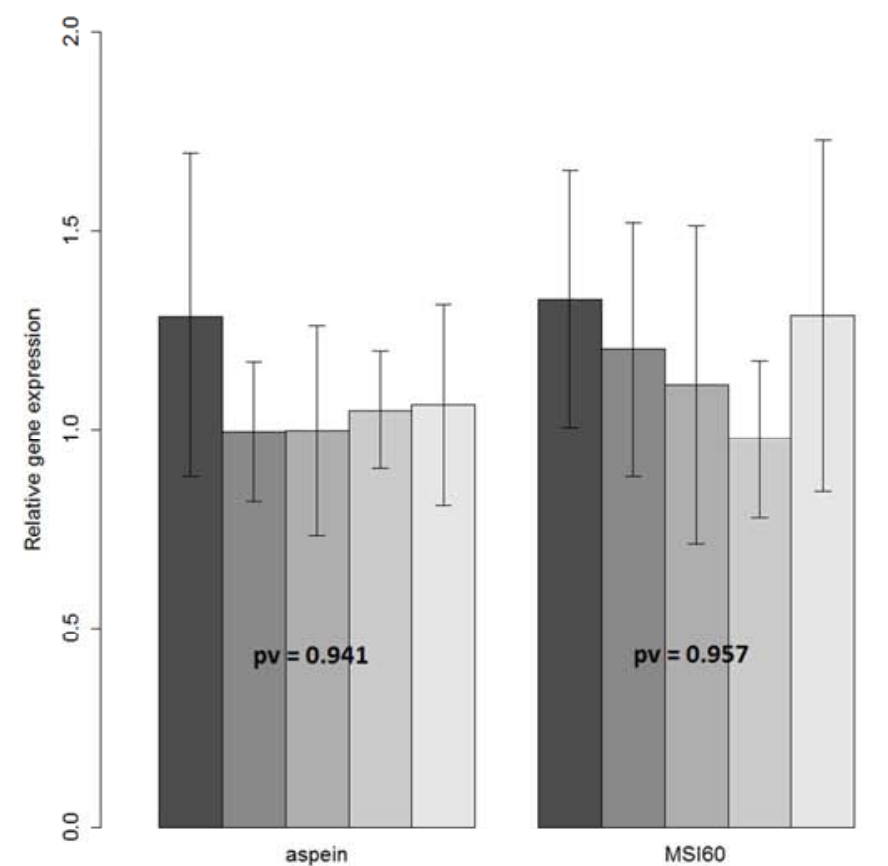

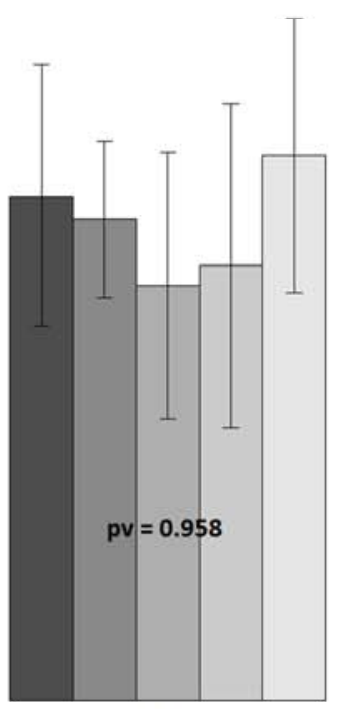

Pif 177

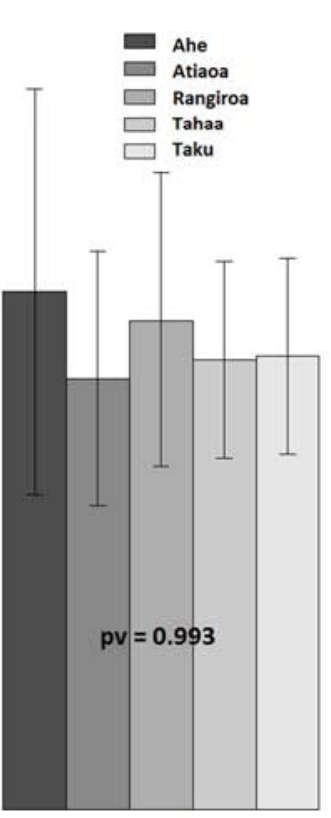

Shematrin 9 